This item was submitted to Loughborough's Research Repository by the author.

Items in Figshare are protected by copyright, with all rights reserved, unless otherwise indicated.

\title{
Review of Le corps nerveux des spectateurs: cinéma et sciences du psychisme de 1900
}

PLEASE CITE THE PUBLISHED VERSION

http://dx.doi.org/10.1080/17460654.2016.1212454

\section{PUBLISHER}

Taylor and Francis @ Simone Natale

\section{VERSION}

AM (Accepted Manuscript)

\section{PUBLISHER STATEMENT}

This work is made available according to the conditions of the Creative Commons Attribution-NonCommercialNoDerivatives 4.0 International (CC BY-NC-ND 4.0) licence. Full details of this licence are available at: https://creativecommons.org/licenses/by-nc-nd/4.0/

\section{LICENCE}

CC BY-NC-ND 4.0

\section{REPOSITORY RECORD}

Natale, Simone. 2019. "Review of Le Corps Nerveux Des Spectateurs: Cinéma Et Sciences Du Psychisme De 1900”. figshare. https://hdl.handle.net/2134/22839. 
Le corps nerveux des spectateurs: Cinéma et sciences du psychisme de 1900, by Mireille Berton, Lausanne, Editions L’Age d’Homme, 2015, 632 pp., b/w illustrations, € 39 (paperback), ISBN 978-2-8251-4268-4.

Mireille Berton's Le corps nerveux des spectateurs is a rich, theoretically sound exploration of the encounters and intercourses between early cinema and the sciences of the mind, such as psychology, psychoanalysis, psychiatry, physiology, and parapsychology. Placed within a growing, international body of literature on the topic (Alovisio 2013; Gordon 2001; Violi, 2004), and focusing especially on the period between the end of the nineteenth and the beginning of the twentieth century, Berton provides a convincing and detailed account of how the figure of the cinematic spectator became the central space within which such encounters were negotiated and redefined. The book characterizes the relationship between the "sciences du psychisme" and the new technology of cinema as an exchange, rather than a transfer. In fact, if the cinematograph and other techniques of the moving image were forced into metaphors to describe the functioning of the psyche in the medical and psychological sciences, neurological culture also established the conditions and the spectre of possibility to imagine and describe the cinematic experience. The result of this exchange, Berton argues, is the formation of a new subjectivity, in which the cinematic spectator came to embody a new version of the 'corps nerveux' defined as hypersensorial and mimetic.

The book's impressively wide reach is inevitably the source of its strengths as well as its main weaknesses. Yet, Berton succeeds to manage surprisingly well such ambitious task, as she addresses different disciplinary and theoretical perspectives - and we could easily say, different visions of the world -, from the medical sciences to the emerging psychoanalysis, from physiology to spiritualism and parapsychology. Although this breadth results at times in the creation of too many pathways, undermining the creation of a coherent trajectory, one of 
the most significant contributions of Berton's analysis is in fact the recognition of the diverse and multiform ways in which cinematic technologies, situations, and spectators are conceptualized and portrayed. The author resists to the temptation of forcing the materials of her study into a univocal claim. The wide body of textual sources, examined with the careful and meticulous approach of a historian, tell in fact a very different story, within which the conceptualization of cinema emerges not as one but rather as a plurality of epistemological and representational models. Such plurality corresponds, from the side of the psychological sciences, to the theorization of a mental subject whose essence lies in multiform, sometimes even ambivalent and contradictory features; a subject whose high reactivity and receptivity is linked by scientists to the technological innovations of modernity, such as cinema.

The book, a volume of more than 600 pages including the bibliography, starts with two chapters providing a historical overview that reaches back to the eighteenth century and to the creation of an "electro-physiological" imaginary in the nineteenth century, and then proceeds with thematic chapters, examining the specific impact of literature on subjects such as hysteria, hallucinations, or memory. Between the different chapters, the trait d'union is provided by a series of theoretical reflections and historical arguments that develop section after section. Among these is the emphasis on the perceived dangers of cinema and of technology in general. Technophobia has been often recognized as a key element in examinations of societal and cultural approaches to new media (Sturken, Thomas, and BallRokeach 2004; Boddy 2004); yet Berton is able to provide a most comprehensive account, taking into account a manifold spectre of pathologies that were offered as symptoms of a societal crisis triggered by the challenges of technological, scientific, and cultural progress. In this context, the new medium of cinema became the symbol as well as the proposed cause of a new characterization of the modern subject that emphasizes their psychological sensitivity and vulnerability to sensorial stimulation. Rather than limiting her exploration to the 
specificity of cinema, Berton shows how this discourse was inserted within a wider body of alarmed calls about the effects of popular spectacles on the mental health of readers and viewers, which originated much before the introduction of cinema.

Among the varied interpretative frameworks within which the new technology of cinema is embedded, Berton points to the well-established discourse that sees social and technological transformations as causes of a sensorial vertigo resulting in the failure to distinguish between hallucination and reality. The reception of cinema as a new medium takes up and at the same time renovates such discourse. Especially since the last decades of the nineteenth century, hallucination had started to be described through metaphors that focused on technologies for the mechanical reproduction of images, such as photography and, later, cinema. In this context, hallucinations became associated with the projection of images and sound that develop upon a mental (maybe even “virtual,” Berton suggests) screen. Following this direction within the psychological and physiological science, Berton provides a thorough and useful trajectory that, ultimately, provides further ground to interrogate how and why hallucinations and dreams came to be represented in film through the use of techniques such as superimposition (see Natale 2016, 135-69). In the conclusion, she argues that cinema provided a converging point between a "concrete space" (the projection of moving images before a group of spectators) and a "psychic space” (the projection of mental images conceptualised through metaphors of audiovisual devices). It is at the intersection between these two parallel configurations that cinema dissolves into a metaphor of the mind.

A further key argument that develops through several chapters is the claim that the representation of the cinematic spectator draws from a range of representations previously assigned mainly to the feminine subject. As Berton points out, "the spectator was a female spectator (spectatrice)" (p. 557): the model of the spectator emerging at the dawn of cinema was characterized, in other words, by a representation of the feminine body as a site for a 
wide range of pathological tendencies (including but not limited to hysteria) that converge to the characterization of women as sensitive subjects, prone to a multiplicity of sensory, bodily and mental reactions. This imagination of the feminine subject, Berton contends, was then adapted into the more abstract, non-gendered characterization of the cinematic public.

As mentioned above, the breadth of the book is at the same time the source of its strength, but also of its limitations and weaknesses. The choice of a narrower focus would have benefited the clarity of the book's contributions and provided an antidote to the sometimes excessively didactic approach through which such a wide range of topics, theories and perspectives are presented and discussed. In the attempt to develop her comprehensive approach, Berton sometimes fails to fully acknowledge the complexity of this attempt, especially when she underestimates the peculiarity and differences between national contexts. While it might be true that medical research can only be approached from a transnational approach, as Berton points out, a more nuanced perspective that recognizes and takes into account the cultural specificity of particular representations of the mind and the cinematic apparatus would have further improved the usefulness of Berton’s insights.

This notwithstanding, the richness of materials examined and its impressive breadth makes this book a useful resource for scholars in fields such as early cinema, visual culture, and media history, especially those interested in historical conceptualizations of spectatorship and different viewing positions, as well as in the relationship between media, science, and culture. Complementing Berton’s previous works in media archaeology (Weber and Berton 2009) and on the relationship between film, magic and the supernatural (Berton 2015), Le corps nerveux des spectateurs provides a strong contribution to approaches that contextualize and re-write film history beyond the limits of medium specificity, and underpin its connections with broader histories of the social, economic, scientific and cultural space. 


\section{Works cited}

Alovisio, Silvio. 2013. L'occhio sensibile: cinema e scienze della mente nell'Italia del primo Novecento. Torino: Kaplan.

Berton, Mireille. 2015. “The 'magism’of Cinema and Imaginary Spiritism in France at the Beginning of the Twentieth Century.” Early Popular Visual Culture 13 (2): 113-33.

Boddy, William. 2004. New Media and Popular Imagination: Launching Radio, Television, and Digital Media in the United States. Oxford: Oxford University Press.

Gordon, Rae Beth. 2001. Why the French Love Jerry Lewis: From Cabaret to Early Cinema. Stanford, Calif.: Stanford University Press.

Natale, Simone. 2016. Supernatural Entertainments: Victorian Spiritualism and the Rise of Modern Media Culture. University Park, PA: Pennsylvania State University Press.

Sturken, Marita, Douglas Thomas, and Sandra Ball-Rokeach, eds. 2004. Technological Visions: The Hopes and Fears That Shape New Technologies. Philadelphia: Temple University Press.

Violi, Alessandra. 2004. Il teatro dei nervi: Fantasmi del moderno da Mesmer a Charcot. Milano: Bruno Mondadori.

Weber, Anne-Katrin, and Mireille Berton. 2009. La télévision du téléphonoscope À YouTube : Pour une archéologie de l'audiovision. Lausanne: Antipodes. 